\title{
INHIBITORY EFFECTS OF ACUTE AND CHRONIC TREATMENTS WITH ADRENOCORTICOTROPIN-RELEASING HORMONE ON THE LEYDIG CELLS OF THE RAT TESTIS
}

\author{
Giuseppina Mazzocchi ${ }^{1}$, Ludwik K. Malendowicz ${ }^{2}$, Virgilio Meneghelli ${ }^{1}$ and Gastone G. \\ NUSSDORFER $^{1}$ \\ ${ }^{1}$ Department of Anatomy, University of Padua, 35121 Padua, Italy, and ${ }^{2}$ Department of Histology and Embryology, School of \\ Medicine, University of Poznan, Póznan, Poland
}

\begin{abstract}
The effects of acute and chronic administrations of corticotropin-releasing hormone (CRH) on the secretory activity and growth of Leydig cells of hypophysectomized/human chorionic gonadotropin (hCG)-treated rats were investigated by radioimmunoassay (RIA) and morphometry. CRH bolus intraperitoneal injection (30 or $300 \mathrm{pmol} / \mathrm{kg}$ ) did not affect basal plasma testosterone concentration (PTC), but it did notably blunt the hCG-induced rise in PTC. Prolonged (7-day) subcutaneous infusion with CRH ( 30 or $300 \mathrm{pmol} / \mathrm{kg} / \mathrm{h}$ ) lowered basal PTC and evoked a marked decrease in the volume of testis, number of Leydig cells per testis and volumes of Leydig cells and their nuclei. Electron microscopic stereologic analysis revealed that the Leydig-cell atrophy induced by the highest dose of CRH was due to decreases in the volume of all the organelles involved in cholesterol and steroid synthesis (i.e. mitochondria, smooth endoplasmic reticulum and peroxisomes), and was associated with a striking accumulation of lipid droplets (i.e. the intracellular stores of cholesterol). Isolated atrophic Leydig cells displayed a notable reduction in both their basal and hCG-stimulated testosterone secretion. These findings indicate that $\mathrm{CRH}$ is able to acutely depress the hCGenhanced secretion of testosterone in vivo, and, when chronically administered, to inhibit the growth and steroidogenic capacity of rat Leydig cells, without interfering with the hypophyseal release of gonadotropins.
\end{abstract}

Pro-opiomelanocortin (POMC) is produced by both Leydig cells and spermatocytes $(6,15)$, and corticotropin-releasing hormone $(\mathrm{CRH})$ is reported to stimulate $\beta$-endorphin secretion in primary cultures of rat Leydig cells (13). $\beta$-Endorphin in turn acts as a paracrine inhibitor of Sertoli cells by blocking cyclic-AMP-mediated spermatogenic action of FSH (16). In vitro data also indicate that CRH is able to depress human chorionic gonadotropin (hCG)-stimulated secretory activity of rat Leydig cells (33).

To gain insight into the possible physiological role of $\mathrm{CRH}$ as a modulator of testis function, it seemed worthwhile to examine the in vivo effects of acute and chronic administrations of $\mathrm{CRH}$ on the secretory activity and growth of Leydig cells in rats.
Since CRH is the physiologic stimulator of the release of POMC-derived peptides by pituitary corticotropes (see 4, for review), and ACTH has been reported to enhance testosterone secretion in adult male rats (1), we employed hypophysectomized $(\mathrm{Hx})$ rats treated with maintenance doses of hCG.

\section{MATERIALS AND METHODS}

Male Wistar rats $(300 \pm 30 \mathrm{~g}$ in body weight) were purchased from Charles-River (Como, Italy). A number of animals were hypophysectomized by the parapharyngeal approach, and the completeness of the operation was checked at the time of autopsy, by inspecting sella turcica under the dissecting microscope. Moreover, sellae turcicae of 
randomly chosen rats were processed for light microscopy and serially cut: the histologic examination never revealed remnants of pituitary tissue. Other rats were sham-operated (control rats). On the third day after hypophysectomy, groups of rats were subcutaneously infused for 7 days (Alzet osmotic pumps Mod. 2001; Alza, Palo Alto, U.S.A.) with hCG (Serono, Rome, Italy) dissolved in $0.9 \% \mathrm{NaCl}$ vehicle (1 IU hCG/ $\mathrm{kg} / \mathrm{h}$ ), in order to maintain the growth and secretory activity of their testes. A number of $\mathrm{Hx}$ animals were infused with the vehicle.

\section{Acute Experiment}

On the 10th day after hypophysectomy, a group of hCG-infused rats received a bolus intraperitoneal injection of $100 \mathrm{IU} / \mathrm{kg}$ hCG dissolved in $0.2 \mathrm{ml}$ of $0.9 \% \mathrm{NaCl}, 60 \mathrm{~min}$ before the sacrifice. Another group of rats was injected with the vehicle. A number $(n=8)$ of rats in each of the two groups had intraperitoneally received together with hCG increasing doses $(3,30$ or $300 \mathrm{pmol} / \mathrm{kg}$ ) of CRH (human and rat, synthetic; Sigma, St. Louis, U.S.A.).

\section{Chronic Experiment}

Three groups $(n=8)$ of $\mathrm{Hx} / \mathrm{hCG}$-infused rats had CRH in the infusion vehicle $(3,30$ or $300 \mathrm{pmol} / \mathrm{kg} /$ h). The animals were decapitated between 1000 and 1100 , and their trunk blood and testes were collected.

Testosterone was extracted from heparinized plasma and extracts were chromatographed on Sephadex LH-20 columns. Plasma testosterone concentration (PTC) was assayed by radioimmunoassay (RIA) (T-RIA kit; IRE Sorin, Vercelli, Italy. Sensitivity, $10 \mathrm{pg} /$ tube). Intra- and interassay variations: $6 \%$ and $9 \%$, respectively.

The testes of rats from the chronic experiment were employed for morphometric evaluations. The left testis was prefixed in situ (11), and then cut into two halves, which were processed for light or electron microscopy, as previously described (3). The right testis was weighed, and its volume was calculated by pyknometry (24); then those obtained from $\mathrm{Hx} / \mathrm{hCG}$-infused rats and $\mathrm{Hx} /$ hCG-infused rats plus $300 \mathrm{pmol} / \mathrm{kg} / \mathrm{h} \mathrm{CRH}$ were employed to isolate Leydig cells (see below). The following morphometric parameters were calculated on light micrographs of $6 \mu \mathrm{m}$-thick paraffin and $0.5 \mu \mathrm{m}$ thick epon sections: volume and number of Leydig cells and volume of their nuclei (Weibel-Gomez method). In the two groups of animals cited above, the following stereologic parameters of Leydig cells were measured on electron micrographs of $600 \mathrm{~nm}$ thick epon sections: volumes of mitochondrial, lipid-droplet, dense-body and peroxisome compartments (differential point counting), and surface area per cell of mitochondrial cristae, smooth (SER) and rough (RER) endoplasmic reticulum and Golgi apparatus (crossing method). The morphometric and stereologic techniques, as well as the sampling procedures were those described by Weibel (35), as detailed by Andreis et al. (3).

After weighing, right testes were decapsulated, and Leydig cells were isolated according to Van Damme et al. (34), as described earlier (3). Isolated cells from each rat were incubated partly with hCG $(5 \mathrm{IU} / \mathrm{ml})$ and partly without hCG. The incubation was carried out in a shaking bath at $37^{\circ} \mathrm{C}$ for $90 \mathrm{~min}$, in an atmosphere of $95 \% \mathrm{O}_{2}$ and $5 \% \mathrm{CO}_{2}$. At the end of the experiment, the incubation tubes were centrifuged at $4^{\circ} \mathrm{C}$ and testosterone concentration in the supernatants was measured by RIA, as described above. All the samples were analyzed in the same assay, and intra-assay variation was $6 \%$.

The data were averaged per experimental group and SE was calculated. The statistical comparison of the results was performed by ANOVA, followed by the Student's $t$-test or the Multiple Range test of Duncan.

\section{RESULTS}

\section{Acute Experiment}

Hypophysectomy decreased PTC $(-72 \%)$, and the infusion with hCG restored this parameter to the control value. Acute hCG administration elicited a 6-fold surge in PTC. CRH bolus injection did not significantly affect basal PTC. However, CRH, when injected at a dose of 30 or $300 \mathrm{pmol} / \mathrm{kg}$, notably blunted (about -60\%) the hCG-induced rise of PTC (Fig. 1).

\section{Chronic Experiment}

Again the infusion with hCG annulled the hypophysectomy-induced fall in PTC $(-75 \%)$. CRH infusion at a rate of 30 or $300 \mathrm{pmol} / \mathrm{kg} / \mathrm{h}$ decreased PTC by $-39 \%$ and $-75 \%$, respectively (Table 1 ).

Hypophysectomy caused significant reductions in the volume of testis $(-33 \%)$, number of Leydig cells per testis $(-35 \%)$, volume of Leydig cells $(-39 \%)$ and volume of Leydig-cell nucleus $(-39 \%)$. The infusion with hCG completely re- 


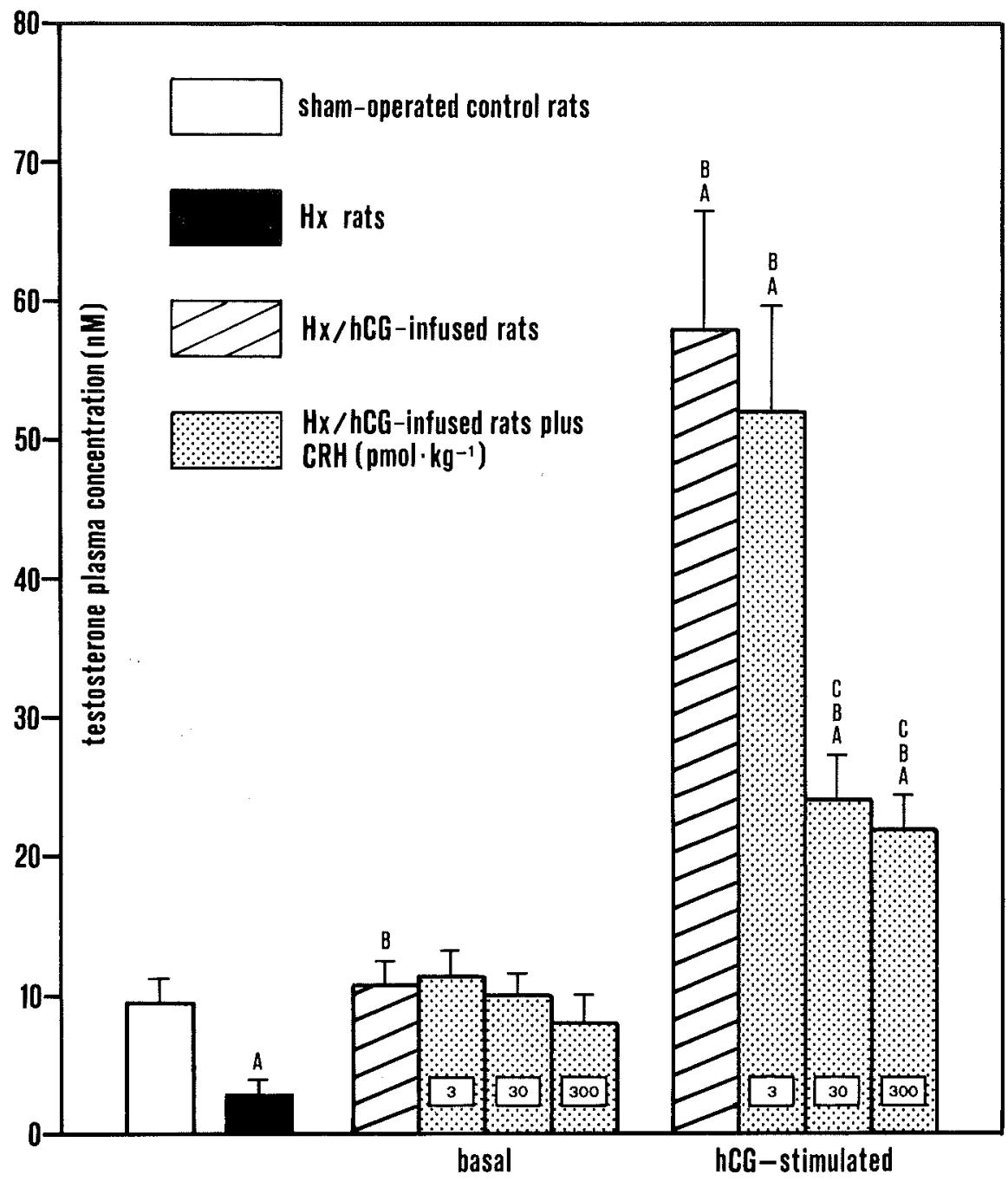

Fig. 1 Effect of bolus intraperitoneal injection of CRH on basal and hCG (100 IU/ $\mathrm{kg})$-stimulated PTC of $\mathrm{Hx} / \mathrm{hCG}$-infused rats. Values are means $\pm \mathrm{SE}(\mathrm{n}=8)$. A, $P<0.01$ from control rats; B, $P<0.01$ from $\mathrm{Hx}$ rats; C, $P<0.01$ from $\mathrm{Hx} / \mathrm{hCG}$ infused rats (Multiple Range test of Duncan)

stored these morphometric parameters to the control values (Table 1). CRH infusion at a rate of $3 \mathrm{pmol} / \mathrm{kg} / \mathrm{h}$ did not change any of these morphometric parameters in $\mathrm{Hx} / \mathrm{hCG}$-treated rats. However, CRH, when infused at a rate of 30 or 300 $\mathrm{pmol} / \mathrm{kg} / \mathrm{h}$, evoked significant decreases in the volume of testis $(-20 \%$ and $-36 \%)$, number of Leydig cells per testis $(-25 \%$ and $-42 \%)$, volume of Leydig cells $(-28 \%$ and $-41 \%)$ and volume of Leydig-cell nucleus $(-34 \%$ and $-50 \%)$ (Table 1$)$.

Stereology (Table 2) showed that the fall in the average volume of Leydig cells of Hx/hCG-treated rats induced by CRH $(300 \mathrm{pmol} / \mathrm{kg} / \mathrm{h})$ was coupled with significant decreases in the volumes of the mitochondrial $(-38 \%)$ and peroxisome compartments $(-53 \%)$, and in the surface areas per cell of mitochondrial cristae $(-45 \%)$, SER tubules $(-49 \%)$ and Golgi cisternae $(-59 \%)$. The volume of the lipid-droplet compartment underwent a 3.6fold rise. No changes were noted in the other stereological parameters.

The exposure to hCG caused a 10-fold surge in testosterone production by isolated Leydig cells from $\mathrm{Hx} / \mathrm{hCG}$-treated rats. CRH infusion (300 
Table 1 Effects of Chronic Infusion of CRH on the Function and Morphology of Hx/hCG-Treated Rats

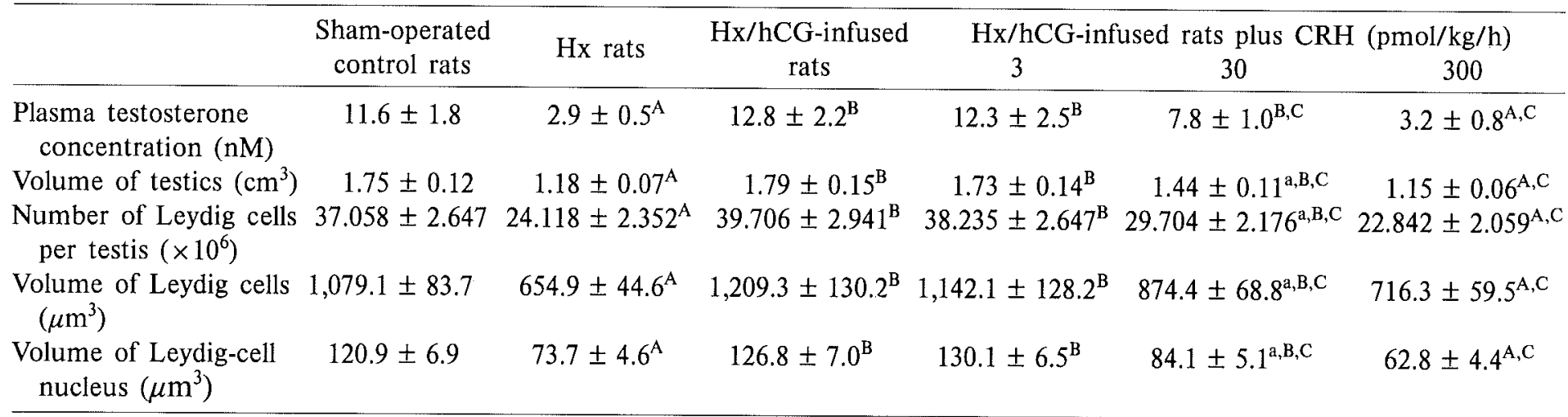

Values are means $\pm \mathrm{SE}(\mathrm{n}=8)$. a and $\mathrm{A}, P<0.05$ and $P<0.01$ from control rats; $\mathrm{B}, P<0.01$ from $\mathrm{Hx}$ rats; $\mathrm{C}, P<0.01$ from $\mathrm{Hx} / \mathrm{hCG}$ treated rats (Multiple Range Test of Duncan)

Table 2 Effect of CRH Infusion ( $300 \mathrm{pmol} / \mathrm{kg} / \mathrm{h}$ ) on the Stereologic Parameters of Leydig Cells

\begin{tabular}{|c|c|c|c|c|}
\hline \multirow[b]{2}{*}{$\begin{array}{l}\text { Volume of mitochondrial } \\
\text { compartment }\left(\mu \mathrm{m}^{3} / \text { cell }\right)\end{array}$} & \multicolumn{2}{|c|}{$\begin{array}{l}\text { Hx/hCG-infused } \\
\text { rats }\end{array}$} & \multicolumn{2}{|c|}{$\begin{array}{l}\mathrm{Hx} / \mathrm{hCG} \text {-infused } \\
\text { rats plus CRH }\end{array}$} \\
\hline & $135.1 \pm$ & 12.9 & $84.1 \pm$ & $8.2^{*}$ \\
\hline $\begin{array}{l}\text { Surface area of } \\
\text { mitochondrial cristae } \\
\left(\mu \mathrm{m}^{2} / \text { cell }\right)\end{array}$ & \multicolumn{2}{|c|}{$60,274.2 \pm 7,360.5$} & \multicolumn{2}{|c|}{$33,128.2 \pm 4,628.7^{*}$} \\
\hline $\begin{array}{l}\text { Surface area of SER } \\
\left(\mu \mathrm{m}^{2} / \text { cell }\right)\end{array}$ & \multicolumn{2}{|c|}{$67,548.3 \pm 7,860.5$} & \multicolumn{2}{|c|}{$35,481.9 \pm 5,104.1^{*}$} \\
\hline $\begin{array}{l}\text { Surface area of Golgi } \\
\text { apparatus }\left(\mu \mathrm{m}^{2} / \text { cell }\right)\end{array}$ & $6,048.9 \pm$ & 675.5 & $2,447.2 \pm$ & $327.8^{*}$ \\
\hline $\begin{array}{l}\text { Surface area of RER } \\
\left(\mu \mathrm{m}^{2} / \text { cell }\right)\end{array}$ & $3,145.8 \pm$ & 353.0 & $2,905.5 \pm$ & $359.8^{*}$ \\
\hline $\begin{array}{l}\text { Volume of lipid-droplet } \\
\text { compartment }\left(\mu \mathrm{m}^{3} / \text { cell }\right)\end{array}$ & $2.4 \pm$ & 0.5 & $8.6 \pm$ & $1.5^{*}$ \\
\hline $\begin{array}{l}\text { Volume of dense-body } \\
\text { compartment }\left(\mu \mathrm{m}^{3} / \text { cell }\right)\end{array}$ & $4.7 \pm$ & 1.1 & $5.0 \pm$ & $1.0^{*}$ \\
\hline $\begin{array}{l}\text { Volume of peroxisome } \\
\text { compartment }\left(\mu \mathrm{m}^{3} / \text { cell }\right)\end{array}$ & $21.3 \pm$ & 2.8 & $9.9 \pm$ & $1.7^{*}$ \\
\hline
\end{tabular}

Values are means $\pm \mathrm{SE}(\mathrm{n}=8) .{ }^{*} P<0.01$ (Student's $t$-test)

Table 3 Effect of CRH Infusion (300 pmol/ $\mathrm{kg} / \mathrm{h}$ ) on Testosterone Production by Isolated Leydig Cells

\begin{tabular}{lcr}
\hline \multicolumn{1}{c}{$\left(\mathrm{pmol} / 10^{5}\right.$ cells $\left./ \mathrm{h}\right)$} & $\begin{array}{c}\text { Hx/hCG-infused } \\
\text { rats }\end{array}$ & $\begin{array}{r}\text { Hx/hCG-infused } \\
\text { rats plus CRH }\end{array}$ \\
\hline Basal secretion & $50.6 \pm 7.2$ & $31.1 \pm 5.3^{*}$ \\
hCG (5 IU/m1)-stimulated secretion & $498.2 \pm 69.5$ & $289.5 \pm 30.2^{*}$ \\
\hline
\end{tabular}

Explanations as in Table 2 
$\mathrm{pmol} / \mathrm{kg} / \mathrm{h}$ ) significantly reduced both basal $(-39 \%)$ and hCG-stimulated $(-42 \%)$ testosterone secretion (Table 3).

\section{DISCUSSION}

Our present in vivo data indicate that $\mathrm{CRH}$ is able to acutely depress the hCG-stimulated (but not the basal) testosterone secretion by Leydig cells (as indicated by PTC) of $\mathrm{Hx} / \mathrm{hCG}$-replaced rats. This finding appears to be in keeping with a previous in vitro study, showing that $\mathrm{CRH}$ does not interfere with hCG binding to rat Leydig cells, but probably inhibits adenyl cyclase/hCG-receptor coupling (33). However, it must be noted that the highest dose of CRH causes an evident decrease in the basal PTC $(-26 \%)$, which is not significant due to the rather elevated intra-group variability. This point requires further investigation, since an in vivo acute effect of CRH on basal testosterone secretion could be conceivably due to the continuous exposure of Leydig cells to circulating gonadotropins.

Chronic CRH infusion causes a marked reduction in the basal PTC of $\mathrm{Hx} / \mathrm{hCG}$-administered rats, as well as an evident testis atrophy, coupled with a notable decrease in both the number and average volume of Leydig cells. Leydig-cell atrophy is mainly due to the decrease in the mitochondrial compartment (associated with a parallel fall in the surface area of cristae) and SER. Mitochondria and SER are the two organelles in which the enzymes of testosterone synthesis are located (see 27, for review), and several lines of evidence indicate that in other steroidogenic cells (e.g. adrenocortical cells) the changes in the surface area per cell of mitochondrial cristae and SER membranes are associated with corresponding changes in the activity per cell of some key steroidogenic enzymes (see 25 , for reference). Hence, the decrease in these two stereologic parameters may be easily correlated with the reduction in both basal and hCG-stimulated testosterone secretion observed in isolated Leydig cells of rats chronically treated with CRH. Current evidence suggests that gonadotropins, via cyclic-AMP, exert their trophic effect on Leydig cells by enhancing transcription (and translation) of some enzymes of testosterone synthesis (e.g. cytochromes P-450 ${ }_{\text {scc }}$ and P-450 $0_{17 a}$ ) (see 2, 14, 23, 29, for reviews). Since CRH has been reported to inhibit hCG-stimulated cyclic-AMP production (33), it appears reasonable to propose that the mechanism underlying the long-term inhibitory effect of CRH on rat Leydig cells may involve the repression of $d e$ novo synthesis of structural and enzymatic proteins. A reduced steroidogenic machinery may explain why after prolonged exposure to CRH, not only hCG-stimulated, but also basal secretory activity is notably decreased in Leydig cells. The striking nuclear atrophy is also in keeping with a depressed protein synthesis in Leydig cells of CRHinfused rats (see 25, 26, for reviews).

Lipid droplets in steroidogenic cells contain cholesterol and cholesterol esters $(10,25)$, which in Leydig cells are mainly derived from endogenous synthesis (18). Thus, the decreased utilization of cholesterol in testosterone synthesis may account for the conspicuous lipid-droplet accumulation in Leydig cells of CRH-infused rats. Also the atrophy of the Golgi apparatus is in keeping with the reduced steroidogenic capacity of Leydig cells. In fact, some in vitro and in vivo investigations employing monensin, a disruptor of the Golgi apparatus, show that this organelle is integral to steroidogenesis, at least in adrenocortical cells $(7-9,21)$.

The decrease in the peroxisomes observed in Leydig cells of CRH-infused rats appears to be a rather puzzling finding, inasmuch as these organelles do not contain steroidogenic enzymes (14, 22). Peroxisomes, at least in hepatocytes, are actively engaged in cholesterol synthesis $(5,27,31$, 32 ), since they contain $3 \beta$-hydroxy-3-methylglutaryl-coenzyme A (HMG-CoA) reductase $(19,20)$, the rate-limiting enzyme of this process (17). A large body of data suggests that transcription of HMB-CoA reductase gene is negatively regulated by the level of the intracellular cholesterol pool (see 17 , for review). In light of these considerations, it could be tentatively proposed that the CRHinduced fall in the number of peroxisomes may be the morphologic counterpart of the reduced endogenous cholesterol synthesis due to the rise in the intracellular cholesterol content (evidenced by lipid-droplet accumulation), which in turn follows the decreased utilization of this precursor in testosterone synthesis.

In conclusion, our present findings indicate that $\mathrm{CRH}$ is able in vivo to acutely depress hCG-stimulated secretion of testosterone by rat Leydig cells, and, when chronically administered, to inhibit the growth and steroidogenic capacity of these cells.

Caution, however, must be taken in hypothesizing the physiological relevance of the CRH action on Leydig cells. In fact, it must be noted that clearcut effects were obtained only by administering very high doses of CRH (10 or $100 \mathrm{pmol} / \mathrm{rat})$. We have not actually assayed the concentration reach- 
ed by CRH in the plasma of treated rats; however, by assuming $10-12 \mathrm{ml}$ of total plasma volume per rat (28), we can estimate blood levels of $\mathrm{CRH}$ of about $10^{-10}-10^{-9} \mathrm{M}$. These values exceed that found in normal rats (about $2 \times 10^{-12} \mathrm{M}$ ) (36) by more than 2 or 3 order of magnitude. The same is true for the in vitro inhibitory effect of $\mathrm{CRH}$, which was observed at a concentration $10^{-7} \mathrm{M}$ (33). However, evidence is available in favor of an autocrine/paracrine action of CRH on the function of testis: CRH and CRH-mRNA are present in the testis interstitial tissue $(30,37)$ and CRH binding sites are demonstrated in rat Leydig cells $(12,33)$. Thus, it seems conceivable that a local production of CRH may easily determine an intra-testicular concentration of this peptide of the order of those found to be effective in our own and previous investigations.

Received 12 June 1992; and accepted 19 June 1992

\section{REFERENCES}

1. Amario A., Perello A. and Lopez-Calderon A. (1986) Adrenocorticotropin administration increases testosterone secretion in adult male rats. Life Sci. 39, 1119-1122

2. Anakwe O. O. and Payne A. H. (1987) Noncoordinate regulation of de novo synthesis of cytochrome $\mathrm{P}-450$ cholesterol side-chain cleavage and cytochrome P-450 17 $\alpha$-hydroxylase/ $\mathrm{C}_{17-20}$ lyase in mouse Leydig cell cultures: relation to steroid production. Mol. Endocrinol. 1, 595-603

3. Andreis P. G., Cavallini L., Malendowicz L. K., Belloni A. S., Rebuffat P., Mazzocchi G. and Nussdorfer G. G. (1989) Morphological and functional responses of rat Leydig cells to a prolonged treatment with human chorionic gonadotropins. J. Submicrosc. Cytol. Pathol. 21, 703-712

4. Antoni F. A. (1986) Hypothalamic control of adrenocorticotropin secretion: advances since the discovery of 41-residue corticotropin-releasing factor. Endocrine Rev. 7, 351378

5. Appelkvist E.-L., Reinhart M., Fischer R., Billheimer J. and Dallner G. (1990) Presence of individual enzymes of cholesterol biosynthesis in rat liver peroxisomes. Arch. Biochem. Biophys. 282, 318-325

6. Bardin C. W., Chen C.-L. C., Morris P. L., Gerendai I., Boitani C., Liotta A. S., Margioris A. and Krieger D. T. (1987) Proopiomelanocortin-derived peptides in testis, ovary, and tissues of reproduction. Recent Prog. Horm. Res. $43,1-28$

7. Cheng B., Horst I. A. and Kowel J. (1985) The Golgi apparatus and adrenal function: The effects of monensin on adrenocorticotropic hormone-stimulated steroidogenesis. Arch. Biochem. Biophys. 239, 508-516

8. Cheng B., Horst I. A. and Kowal J. (1987) The effect of monensin on inhibition of steroidogenesis and disruption of the Golgi complex in adrenal cells are both reversible! Endocrine Res. 13, 243-250

9. Cheng B., Horst I. A. and Kowal J. (1990) Further characterization of the inhibitory effect of monensin on adrenal steroidogenesis. J. Steroid Biochem. 36, 493-499

10. Christensen A. K. (1975) Leydig cells. In Handbook of Physiology (ed. GreeP R. O. and Astwood E. B.) Sect. 7, Vol. 5. American Physiological Society, Washington D. C., pp. $57-94$

11. Dal LAGo A. and LuCKe S. (1973) A method of fixing rat testis for light and electron microscopy. Stain Technol. 48, 289-295

12. Dave J. R., Eiden L. E. and Eskay R. L. (1985) Corticotropin-releasing factor binding to peripheral tissue and activation of the adenylate cyclase-adenosine $3^{\prime}, 5^{\prime}$-monophosphate system. Endocrinology 116, 2152-2159

13. Eskeland N. L., Lugo D. I., Pintar J. E. and Schachter B. S. (1989) Stimulation of $\beta$-endorphin secretion by corticotropin-releasing factor in primary rat Leydig cell cultures. Endocrinology 124, 2914-2919

14. EwING L. L. (1989) The trophic effect of luteinizing hormone on the rat Leydig cell. J. Amer. Coll. Toxicol. 8, 473485

15. Fabbri A., Knox G., Buczko E. and Dufau M. L. (1988) $\beta$ Endorphin production by the fetal Leydig cell: regulation and implications for paracrine control of Sertoli cell function. Endocrinology 122, 749-755

16. Fabbri A., Tsai-Morris C. H., Luna S., Fraioli F. and Dufau M. L. (1985) Opiate receptors are present in the rat testis. Identification and localization in Sertoli cells. Endocrinology 117, 2544-2546

17. Goldstein J. L. and BRown M. S. (1990) Regulation of the mevalonate pathway. Nature 343, 425-430

18. GWynne J. T. and Strauss J. F. (1982) The role of lipoproteins in steroidogenesis and cholesterol metabolism in steroidogenic glands. Endocrine Rev. 3, 299-329

19. Keller G.-A., Barton M. C., Shapiro D. J. and Singer S. J. (1985) 3-Hydroxy-3-methylglutaryl-coenzyme A reductase is present in peroxisomes in normal rat liver cells. Proc. Natl. Acad. Sci. USA 82, 770-774

20. Keller G. A., Parirandeh M. and Krisans S. (1986) 3Hydroxy-3-methylglutaryl coenzyme A reductase localization in rat liver peroxisomes and microsomes of control and cholestyramine-treated animals: quantitative biochemical and immunoelectron microscopical analyses. $J$. Cell Biol. 103, 875-886

21. Magalhaes M. M., Serra T. A. M., Pinto P. and MagalHAES M. C. (1991) The effects of monensin on Golgi complex of adrenal cortex and steroidogenesis. Tissue Cell 23, 209-215

22. Mendis-Handagama S. M. L. C., Zirkin B. R. and Ewing L. L. (1988) Comparison of components of the testis interstitium with testosterone secretion in hamster, rat, and guinea pig testes perfused in vitro. Amer. J. Anat. 181, 1222

23. Miller W. L. (1989) Regulation of mRNAs for human steroidogenic enzymes. Endocrine Res. 15, 1-16

24. Mori H. and Christensen A. K. (1980) Morphometric analysis of Leydig cells in the normal rat testis. J. Cell Biol. 84, 340-354

25. NussDorfer G. G. (1986) Cytophysiology of the adrenal cortex. Int. Rev. Cytol. 98, 1-405

26. Palkovits M. and Fischer J. (1968) Karyometric Investigations. Académiai Kiadó, Budapest

27. Payne A. H., Quinn P. G. and Stalvey J. R. D. (1985) The stimulation of steriod biosynthesis by luteininzing hormone. In Luteinizing Hormone Action and Receptors (ed. Ascoli M.) CRC Press, Boca Raton, pp. 135-172 
28. Reaven E., Kostrna M., Ramachandran J. and Azhar S. (1988) Structure and function changes in rat adrenal glands during aging. Amer. J. Physiol. 255, E903-E911

29. Simpson E. R., Lund J., Ahlgren R. and Waterman M. R. (1990) Regulation by cyclic AMP of the genes encoding steroidogenic enzymes: when the light finally shines... Mol. Cell. Endocrinol. 70, C25-C28

30. Thompson R. C., Seasholtz A. F. and Herbert E. (1987) Rat corticotropin-releasing hormone gene: sequence and tissue-specific expression. Mol. Endocrinol. 1, 363-370

31. Thompson S. L., Burrows R., Laub R. J. and Krisans S. K. (1987) Cholesterol synthesis in rat liver peroxisomes. Conversion of mevalonic acid to cholesterol. J. Biol. Chem. 262, $17420-17425$

32. Thompson S. L. and KRisans S. K. (1990) Rat liver peroxisomes catalyze the initial step in cholesterol synthesis. The condensation of acetyl-CoA units into acetoacetyl-CoA. $J$. Biol. Chem. 265, 5731-5735
33. Ulisse S., Fabbri A. and Dufau M. L. (1989) Corticutrupin-releasing factor receptors and actions in rat Leydig cells. J. Biol. Chem. 264, 2156-2163

34. Van Damme M.-P., Robertson D. M. and Diczfalusy E. (1974) An improved in vitro bioassay method for measuring luteinizing hormone (LH) activity using mouse Leydig cell preparations. Acta Endocrinol. 77, 655-671

35. Weibel E. R. (1979) Stereological Methods. I. Practical Methods for Biological Morphometry. Academic Press, London

36. Yokoe T., Audhya T., Brown C., Hutchinson B., PassaRELLI J. and Hollander C. S. (1988) Corticotropin-releasing factor levels in the peripheral plasma and hypothalamus of the rat vary in parallel with changes in the pituitaryadrenal axis. Endocrinology 123, 1348-1354

37. Yoon D. J., Sklar C. and David R. (1988) Presence of immunoreactive corticotropin-releasing factor in rat testis. Endocrinology 122, 759-761 